New Zealand Journal of Industrial Relations, 1982, 7 61-75

\title{
A failure of voluntarism : the case of joint health and safety committees in Britain
}

\author{
P.B. Beaumont* and J.W. Leopold**
}

This paper sets out the history of the attempt to establish voluntary health and safety committees in Britain, their failure and the attempt to legislate for their development. The impact of this legislation is analysed and the paper concludes by presenting a framework, which it is argued, would be developed for analysing the impact of legislation in Britain and in other countries such as New Zealand.

\section{Introduction}

A much quoted observation of Phelps Brown $(1959$, p.355) in the late 1950 s was that "When British industrial relations are compared with those of the other democracies, they stand out because they are so little regulated by law". However, the position has changed so substantially since then that Lewis (1976, p.15) was able to comment that "In 1975 it would seem that the one indubitably fundamental and irreversible trend is the everincreasing extent of the legal regulation of the British system of industrial relations". In view of this substantially changed state of affairs in Britain, a fundamental task for industrial relations scholars is to, first, identify the reasons for this change, and then secondly, to consider the impact and implications of this change for union-management relations at the national level and, perhaps more importantly, at the level of the individual employment establishment. These questions are not, of course, unique to the British system in that they are obviously relevant to any industrial relations system where such legislative based changes have come about, particularly over a relatively short space of time.

Accordingly, this paper seeks to take a first step in the direction of trying to answer the above two questions by means of a specific illustration, namely the history of the attempt to establish joint health and safety committees on a comprehensive basis in Britain. Specifically, the paper documents the failure to bring about the establishment of such committees on a voluntary basis, which produced, in turn, the attempt to legislate for their development. The impact of this legislation is then documented, and finally we conclude by presenting a framework of analysis that seems potentially valuable in trying to account for variation in the response to such industrial relations legislation at the level of the individual employment establishment. The potential value of this framework of analysis is that it can be used to consider the impact of any industrial relations law giving new rights to unionised employees in any system of industrial relations. In this sense much of the material presented here can be seen to transcend the particular organisational structure discussed here (a joint health and safety committee), and indeed the British system of industrial relations. However, before proceeding to our specific discussion of joint health and safety committees we present an overview of the British industrial relations system and the major challenges and changes to that system that occurred during the course of the 1970s.

* Department of Social and Economic Research, University of Glasgow.

** Centre for Research in Industrial Democracy and Participation, University of Glasgow. 


\section{The Traditional System: Challenges and Changes}

The traditional system of industrial relations in Britain, whose high point was the interwar and immediate post World War II years, was characterised by voluntary collective bargaining conducted very largely at the industry level by various multi-union and multiemployer negotiating bodies. However, during the 1970s virtually all of these traditional aspects of the British industrial relations system were either changed to a substantial extent, or at least were exposed to serious challenges, in some cases for the first time. This period of time witnessed, for example, a continuing strong movement away from industry level, multi-employer bargaining arrangements towards those of single-employer bargaining conducted at the plant, and to a lesser extent the company, level; this bargaining structure change being that recommended in the report of the Donovan Commission in 1968. Furthermore, these years saw the establishment and report of the Bullock Committee of Inquiry on board level worker representation, which represented the first really serious challenge to the long accepted proposition in British industrial relations that collective bargaining was both a necessary and sufficient condition for industrial democracy. In this particular case, it was felt that collective bargaining needed at least to be supplemented by an additional set of structural arrangements so as to ensure union influence over a wide range of subject matter, particularly those matters decided at company level (eg. investment strategy, product development, etc.). However the major change that we are concerned with here was the movement away from a strongly voluntarist system of collective bargaining to a system characterised by a substantial degree of legal regulation.

The essence of the traditional voluntary system of collective bargaining in Britain was the preference for autonomy and self-regulation on the part of both labour and management. This voluntarist tradition, which was at heart an anti-court, rather than an antigovernment, doctrine, came under strong challenge during the 1970 s with a substantial degree of legal regulation being introduced into the system of industrial relations. The early 1970s, for example, witnessed the passage of the Equal Pay Act, the Trade Union and Labour Relations Act, the Industry Act, the Employment Protection Act, the Sex Discrimination Act, the Race Relation Act and the Health and Safety at Work Act. In order to more fully understand the essential nature of this legislative programme one can make use of Kahn-Freund's (1969) perspective on the nature of labour relations law. According to Kahn-Freund, there are three basic functions of labour law:-

(1) being auxiliary to, or assisting the processes of collective bargaining,

(2) restricting or constraining collective bargaining activities, and

(3) regulating or providing statutory standards in areas which might be subjected to collective bargaining.

The legislative programme of the 1970 s was very much a mixture of auxiliary and regulatory law. That is, in contrast to the traditional system where there had been very little law and what existed was essentially negative in character, we now find a system of industrial relations in which both individual employees and unions (as organisational entities) have a variety of positive, legal rights of both a substantive and procedural kind. These legislative developments particularly reflected the influence of membership of the EEC; indeed some parts of the legislative programme in Britain (eg. Part IV of the Employment Protection Act 1975) were taken straight from EEC Directives on the particular subject of concern. These legislative developments can, at least in some sense, be seen as an attempt to develop something of a 'European model' of industrial relations in Britain.

There have been varied management reactions to this programme of industrial relations law which can, at the risk of some over-simplification, be usefully grouped into three basic categories. The first group would argue that this legislative programme has scarcely affected them at all. This is because it has simply made obligatory for all firms those practices which 'enlightened employers' like themselves have long observed. In the longer term, these 
employers would argue that both unions and management will benefit, for example, from a formal disciplinary process, the keeping of detailed personnel records, and, above all, from a more responsible approach to staff recruitment. The second group would argue that in the long term these benefits will certainly come about, but that too large a volume of legislation was passed in too short a time period, so that inevitably there have been some short-run costs to the programme. As one such Managing Director argued: "UK legislation only brings us into line with what the Germans, for example, have had for decades. The problem is that the bulk of our employment protection laws have been introduced in the past three years, and you just can't compress Germany's thirty years of statutes into three years. There are bound to be hiccoughs." (Rees and Robinson, 1979, p.30) The third and final category of management response would be that this legislative programme has essentially been a bad thing in that it has caused managers to grow cautious in their recruitment and companies to employ fewer people; the detailed administrative procedures now required of companies threaten, rather than enhance, good industrial relations, and it has shifted the balance of power too much in favour of the trade union movement.

In order to try and provide some detailed empirical perspective on management attitudes to this legislative programme the Department of Employment commissioned a survey by the Policy Studies Institute. The basic conclusion of this survey exercise, which was conducted in 1977, was as follows:

The main finding to emerge from the study was really how modest had been the influence of an apparently major package of employment legislation. Many employers had developed policies and practices which were in advance of the minimum standards specified in the legislation. Many others, for whom this was not the case, were able to continue much as before, presumably due to the lack of people at their workplaces with the knowledge or inclination to draw attention to the law or invoke its requirements. (Daniel and Stilgoe, 1978, p.84)

One can develop the contents of this quote further by suggesting that the workings and impact of any industrial relations legislation (which provides new rights for unionised employees), at the level of the individual union-management relationship will depend, almost as a matter of definition, on the following factors:

(1) The position with regard to these rights at the individual establishment prior to the passage of the legislation.

(2) The overall nature and quality of the individual union-management relationship into which these new rights are injected.

(3) The extent and way in which the unions choose to exercise these new rights.

It is the nature of factor (1) above that we wish to explore more fully in this paper. In relation to this particular factor, one can broadly distinguish the positions of three basic sub-groups of firms.

(i) Those firms where the rights and arrangements embodied in the legislation have in fact been established on a voluntary basis well before the passage of the legislation. Indeed, it is frequently the arrangements and practices in this sub-group of "bestpractice" firms that has shaped the content of legislation and codes of practice in Britain.

(ii) Those firms that, when legislation on particular rights and arrangements is either imminent or has just been passed, move quickly to comply with its stipulated conditions.

(iii) Those firms who only get round to establishing the arrangements called for in the legislation after a considerable period of time has elapsed. 
In the remainder of this paper we consider the extent (and relevant characteristics) of "establishment response" in the first two categories set out above. This is done by examining, first, the history of the attempt to establish joint health and safety committees on a voluntary basis, and then moving on to consider the nature of the response to the legislation that was ultimately introduced in this area. The first category of consideration is taken up in the next section of the paper.

\section{The Place of Joint Health and Safety Committees: The Voluntary Dimension}

The attempt to encourage the voluntary establishment of joint health and safety committees dates back at least to the early decades of this century. For example, as early as 1913 the Factory Inspectorate stated that:

the experience of several British and American firms shows that, in addition to legal safeguards, reduction of accidents can best be secured by obtaining the interest and co-operation of operatives and officials through safety committees. The number and constitution of such committees will depend on the size of the factory and the nature of the industry ... the duties of these committees are to study the causes of accidents, to suggest and devise suitable means for preventing them, to keep careful records, to make frequent inspection of machinery and plant, and to note any defects and dangers. After some experience the principal safety committee usually drafts a code of safety rules applicable to the particular industry ... (Williams, 1960, p.188)

In addition to the continual urging of the Factory Inspectorate, the TUC and the central employer body at the particular time have also issued joint statements in favour of the voluntary establishment of such committees. However, despite all this verbal encouragement the extent of progress in the voluntary establishment of joint health and safety committees was for long considered unsatisfactory. A Report of the Industrial Safety Sub-Committee of the National Joint Advisory Council of the Ministry of Labour in the mid-1950s revealed that there were "... committees of some kind with functions covering safety ..." in about 60 percent of factories with more than 500 employees, in about 25 percent of factories with between 250 and 500 workers, in less than 10 percent of factories with between 100 and 250 workers and were almost non-existent in factories with less than 100 employees. (Williams, 1960, p.197)

This evidence of the lack of progress in establishing such committees, combined with a rising accident rate over the period 1963-1969, led to union demands for changes to the Factories Acts which would provide for statutory based joint health and safety committees. For example, at the annual meeting of the TUC in 1964 we find a representative of the Amalgamated Union of Foundry Workers moving the following motion:

Congress declares that in order to provide effective safety organisation in industry, the Factories Act should be amended to provide for:

(a) the election of safety delegates, with powers of inspection, by the workers concerned in factories: such powers of inspection to include the right to inspect the scene of an accident and the equipment involved, a right at present available only to miners under the Mines and Quarries Act 1954

(b) the setting up of safety committees in factories

(c) the right of workers' safety delegates to accompany the factory inspector on his visits to factories

(d) the advice of the factory inspector to the firm to be available to the safety committee or safety delegates. 
The General Council in essence opposed this motion, largely on the grounds of possibly reducing employer liability for accidents. However, in the following year a representative of the General Council conceded that "in spite of joint TUC-BEC statements issued two years ago urging improved safety consultation throughout industry the response has been negligible. It was clear from the record that the voluntary approach had failed, and without legislation there would be no substantial development of joint committees. What we are proposing are statutory workshop committees of the kind that operate in Sweden."

Although the TUC began to push for the introduction of statutory based arrangements along the Swedish lines from the mid-1960s their demands did not lead to any immediate legislative changes. They did, however, result in two surveys by the Factory Inspectorate in 1967 and 1969 which were designed to provide detailed information on the extent of committee establishment. The latter survey, for example, revealed that in total only 27 percent of the plants surveyed had a joint health and safety committee, although a further 20 percent did have a general consultative committee that discussed health and safety matters. There was also found to be considerable inter-industry variation in the extent to which joint health and safety committees had been established; the range being from a low of nine percent of plants in clothing and footwear to a high of 56 percent of establishments in gas, electricity and water. These voluntarily established committees tended to be disproportionately concentrated in large plants and in the high accident rate industries.

In addition to these survey returns, the Ministry of Labour published, in 1968, a study of the detailed workings of 20 such joint safety committees. This study indicated that these committees typically meet once a month and tended to discuss accidents and incidents which might have caused accidents, the safety of plant and machinery, gangways and the conditions of floors, methods of material handling, fire precautions and the use of protective clothing and footwear. It was found that the members of these committees had rarely received any specialised training, and that there was very little feedback of the committee workings and decisions to the workforce. These committees were found to be difficult to operate where the general climate of union-management relations was unsatisfactory, and a number of more specific problems, such as poor communication, dissatisfaction with the balance of representation and an inadequate provision of necessary information were also revealed. The committees included in this study were very much advisory bodies. They were rarely allowed to investigate accidents at the time of occurrence, or to undertake inspections of the workplace. Such functions were very much the responsibility of the management appointed safety officer.

The Labour government's eventual response to the results of the two factory inspectorate surveys, and the TUCs continuing pressure for the establishment of statutory based safety committees, was the introduction of the Employed Persons (Health and Safety) Bill in February 1970. This Bill allowed the appointment by a trade union "recognised for the purpose of negotiating terms and conditions of employment" of safety representatives at all factories with more than 10 workers. The functions of these safety representatives were to be to promote co-operation between managers and workers in achieving safe and healthy working conditions, and to carry out inspections in the interests of the workforce. The safety representatives were to have the right to make inspections every three months, or more frequently in the case of accidents, and were to have access to all relevent documents which the employer was required to keep under the terms of the Factories Act. These safety representatives were to be persons with five years' employment in the industry, over 23 years of age and if possible with two years' employment at the factory concerned. In all factories with 100 employees, management was to be required to set up a joint safety committee if requested to do so by the safety representatives. Although this Bill did not, as some unions had hoped, give the safety representatives the right to call in the factory inspector and have work stopped in the event of a serious accident it still aroused considerable employer opposition. 
However, with Parliament being dissolved in June 1970 the Bill did not reach the statute book and the Conservative Government which took office refused to carry on with it. Instead they stated their intention to await the report of the Robens Committee on Workplace Health and Safety (1970-72) which had been set up by the Labour administration. The report of the Robens Committee, while conceding that a statutory provision requiring the appointment of safety representatives and safety committees might be advantageous, refused to recommend such a provision on the grounds that it might prove "too rigid" or "too narrow" in concept. In their view the best way to proceed would be to impose on employers a general duty to consult about joint safety arrangements. Following this report the Conservatives presented a Bill on health and safety at work to Parliament in January 1974. This Bill was largely based on the report of the Robens Committee, although it conceded even less in the way of union involvement. However, the Bill was overtaken by the General Election of the following month and when the Labour Party was returned to power it passed the Health and Safety at Work Act in 1974

\section{The Health and Safety at Work Act 1974}

The Health and Safety at Work Act 1974 (HASAWA 1974) provided an update of previous health and safety at work statutes and regulations, and extended statutory safety protection to some five million workers not covered by the existing Factory Act 1961 and the Office, Shops and Railway Premises Act 1963. It is an enabling Act which imposes broad general duties on employers and employees and allows the newly created Health and Safety Commission to bring forward various pieces of detailed legislation to cover specific areas within the broad health and safety field.

The basic aim of the Act is to create an essentially self-regulatory system for the adoption and observance of safety and health standards and regulations. This approach follows from the Robens Committee's contention that previously too much responsibility for the adoption and observance of workplace health and safety standards had been placed on the law and external inspectorates and too little on employees and management.

The Act for the first time created a general statutory right for workplace health and safety representatives and safety committees to be created and placed a general duty on employers to consult with these representatives (HASAWA Act S2 (6),2 (7)). The Act was later modified by the Employment Protection Act 1975 so that the safety representatives would be chosen solely by recognised trade unions. The detailed rights and powers of safety representatives required the implementation of the Safety Representatives and Safety Committee Regulations 1977, which came into force on 1 October 1978 after a considerable period of delay due largely to financial pressure on local authorities.

However, from 1 October 1978 independent trade unions recognised for the purposes of collective bargaining could appoint safety representatives whom the employer was legally bound to recognise. The method of selection, the representatives chosen and the areas they were to cover were the prerogative of the recognised trade unions, the only proviso being that the person(s) chosen should as far as possible have had two years experience in the type of employment.

Once appointed, trade union safety representatives had extensive rights. These were to investigate potential hazards and dangerous occurrences at the workplace; to examine the causes of accidents at the workplace; to investigate complaints from employees; to make representations on investigations etc to the employer; to conduct inspections under certain statutory regulations; to represent employees in consultation with Factory Inspectors; to receive certain information from inspectors; and, to attend meetings of safety committees. In order to fulfil these functions representatives are allowed time off work for training and in order to carry out their job they are allowed further time off with pay. In addition to these rights two or more safety representatives can request the establishment of a joint health and safety committee. If they do this, then the employer must establish the 
committee within three months and furthermore must consult with the representatives of recognised trade unions about the function and remit of the proposed committee.

With the implementation of the SRSC Regulations on 1 October 1978 extensive statutory backing was given to the creation of both safety representatives and safety committees. Although the Regulations had been delayed for nearly two years they were known in outline for most of that period. Indeed many trade unions pressed for their voluntary implementation before the official date and as our next section shows there is evidence that many employers accepted such union requests and set up arrangements voluntarily in the shadow of the impending legislation.

It is to an analysis of the implementation of these statutory rights that we now turn, using data from two surveys that have been carried out. The data employed here derives from (i) the Warwick University Industrial Relations Research Unit Survey of 970 plants which was conducted between December 1977 and January 1978, and (ii) a survey of 6,630 workplaces conducted by the Health and Safety Executive in the course of their routine inspections in October 1979 . The first survey only concerns joint health and safety committees, while the latter survey also examines the appointment of safety representatives. It is to this latter issue that we now turn.

\section{The Appointment of Health and Safety Representatives}

The Health and Safety Executive's survey covered 6,630 workplaces, employing nearly half a million people. However, the majority of workplaces in the survey had less than 50 employees and significantly, given our earlier finding on size of firm, very few safety representatives had been appointed in such plants. On the other hand when we consider people at work, rather than workplaces, we find that over three-quarters of all employees were represented by a safety representative. The effect of plant size on the likelihood (or not) of having a safety representative is summarised in Table 1 below.

Table 1 Safety representatives in workplaces classified by size

\begin{tabular}{cccc}
\hline $\begin{array}{c}\text { Size band } \\
\text { (number of employees) }\end{array}$ & $\begin{array}{c}\text { Number of } \\
\text { workplaces surveyed }\end{array}$ & \multicolumn{2}{c}{$\begin{array}{c}\text { Workplaces with } \\
\text { safety representatives } \\
\text { appointed under regulations }\end{array}$} \\
\cline { 3 - 4 } & & No. & Percent \\
\hline $1-$ & & 99 & 3 \\
$11-$ & 3,758 & 157 & 13 \\
$26-50$ & 1,190 & 199 & 30 \\
$51-100$ & 670 & 204 & 51 \\
$101-150$ & 406 & 207 & 70 \\
$251-500$ & 294 & 114 & 83 \\
$501-1,000$ & 137 & 71 & 92 \\
1,001 plus & 77 & 90 & 92 \\
All & 98 & 1,141 & 17 \\
\hline
\end{tabular}

Source: Department of Employment gazette February 1981.

Thus we can see clearly that the larger the plant, the more likelihood there was of there being a safety representative. In fact, the majority of medium-sized and large firms do have safety representatives. In accounting for this size influence we must remember that under the Regulations it is independent recognised trade unions which alone have the right to appoint safety representatives. And, as there is a well established strong correlation 
Table 2 Safety representatives in workplaces classified by industry

\begin{tabular}{|c|c|c|c|c|c|}
\hline SIC order & $\begin{array}{c}\text { Number of } \\
\text { employees } \\
\text { in } \\
\text { workplaces } \\
\text { surveyed }\end{array}$ & $\begin{array}{c}\text { Number of } \\
\text { workplaces } \\
\text { surveyed }\end{array}$ & $\begin{array}{c}\text { Average } \\
\text { number of } \\
\text { employees } \\
\text { per workplace }\end{array}$ & $\begin{array}{l}\text { Percentage of } \\
\text { workplaces } \\
\text { with safety } \\
\text { representatives } \\
\text { under } \\
\text { regulations }\end{array}$ & $\begin{array}{l}\text { Percentage of } \\
\text { employees in } \\
\text { workplaces } \\
\text { with safety } \\
\text { representatives }\end{array}$ \\
\hline \multicolumn{6}{|l|}{ Agriculture, forestry, } \\
\hline $\begin{array}{l}\text { fishing (a) } \\
\text { Mining and ayarrving (h) }\end{array}$ & $\begin{array}{r}5,595 \\
-1,500\end{array}$ & 1,129 & 5 & 1 & 15 \\
\hline Mining and quarrying (b) & 13,282 & 314 & 42 & 47 & 85 \\
\hline Food, drink, tobacco & 26,766 & 141 & 190 & 37 & 70 \\
\hline Coal \& Petroleum products & & 14 & 277 & 64 & 81 \\
\hline Chemical \& allied industries & 42,699 & 113 & 378 & 50 & 83 \\
\hline Metal manufacture & 55,228 & 123 & 449 & 51 & 94 \\
\hline Mechanical engineering & 27,395 & 273 & 100 & 22 & 80 \\
\hline Instrument engineering & 1,338 & 31 & 43 & 7 & 43 \\
\hline Electrical engineering & 21,541 & 107 & 201 & 33 & 88 \\
\hline Shipbuilding & 5,423 & 29 & 187 & 21 & 92 \\
\hline $\begin{array}{l}\text { Vehicles } \\
\text { Matol }\end{array}$ & 57,780 & 83 & 696 & 45 & 81 \\
\hline \multicolumn{5}{|l|}{ Metal goods not elsewhere } & 68 \\
\hline Textiles & 15,282 & $\begin{array}{l}356 \\
110\end{array}$ & $\begin{array}{r}45 \\
139\end{array}$ & $\begin{array}{l}18 \\
38\end{array}$ & $\begin{array}{l}88 \\
80\end{array}$ \\
\hline Leather, leather goods \& fur & 146 & 10 & 15 & 0 & 0 \\
\hline Clothing \& footwear & 8,128 & 118 & 69 & 12 & 60 \\
\hline \multicolumn{5}{|l|}{$\begin{array}{l}\text { Bricks, pottery, cement, } \\
\text { glass }\end{array}$} & \\
\hline Timber, furniture, etc & 6,724 & $\begin{array}{l}108 \\
206\end{array}$ & $\begin{array}{l}14 \\
33\end{array}$ & 11 & 67 \\
\hline Paper, printing \& publishing & 18,654 & 173 & 108 & 38 & 88 \\
\hline \multicolumn{6}{|l|}{ Other manufacturing } \\
\hline $\begin{array}{l}\text { industries } \\
\text { Construction }\end{array}$ & 31,312 & 152 & 206 & 23 & 88 \\
\hline Construction & 43,181 & 1,912 & 23 & 4 & 58 \\
\hline $\begin{array}{l}\text { Gas, water \& electricity } \\
\text { Transport \& }\end{array}$ & 1,446 & 54 & 27 & 67 & 90 \\
\hline \& retail) (d) & 3,631 & 148 & 25 & 17 & 67 \\
\hline $\begin{array}{l}\text { Insurance, banking \& business } \\
\text { services (e) }\end{array}$ & 104 & 3 & 35 & 0 & \\
\hline \multicolumn{6}{|l|}{ Professional \& scientific } \\
\hline services (f) & 45,851 & 240 & 191 & 54 & 82 \\
\hline Miscellaneous services (g) & 9,944 & 526 & 19 & 8 & 54 \\
\hline $\begin{array}{l}\text { Public administration \& } \\
\text { defence }\end{array}$ & 9,630 & 115 & 84 & 61 & 74 \\
\hline All & 486,765 & 6,630 & 73 & 17 & 79 \\
\hline
\end{tabular}

Notes:

(a) The sample consists mainly or entirely of agricultural premises.

(b) The sample includes no coal mines, since these are outside the scope of the regulations.

(c) The sample excludes premises subject to inspection by the Railway Inspectorate.

(d) Many workplaces within this Order are subject to local authority inspection.

(e) Workplaces within this Order are mostly subject to local authority inspection - hence tiny sample.

(f) This Order includes hospitals and educational establishments.

(g) Some workplaces within this Order are subject to local authority inspection.

between size of workplace and union recognition, it is the absence of union recognition in small plants that is likely to account, at least partially, for the absence of safety representatives. 
As Table 2 reveals construction and agriculture accounted for just under half of the workplaces surveyed, but only five percent of these workplaces had health and safety representatives and consequently this depressed the overall proportion of workplaces with safety representatives. Without these two industry orders, the percentage having safety representatives would rise from 17 percent to 29 percent. These two orders are characterised by small plants and low levels of unionisation. Among the other industry orders, the low accident rate, low unionised industries of leather, clothing and footwear, and instrument engineering are also the industries which have not invoked the Regulations. At the other end of the league gas, water and electricity is the industry with most safety representatives, with the high accident rate industries such as metal manufacture and coal and petroleum also among the leading industry orders with safety representatives.

There are some discrepancies between the league position of workplaces with safety representatives and the percentage of employees in workplaces with safety representatives. For example workers in transport and communication had the highest percentage of coverage (98 percent) but were much lower down in terms of workplaces covered. Similarly, only 21 percent of workplaces in shipbuilding had safety representatives but those that did, covered 92 percent of the workers concerned. Clearly from these figures a small number of workers in these industry groups are not covered but these workers are spread over a large number of small plants. One other area of note is the high percentage of safety representatives in both professional and scientific services and public administration and defence. These orders largely cover public-sector employment where the government, the instigator of legislation, is employer. They are also areas of high union density and these two factors are likely to give figures for safety representation well beyond what might have been anticipated on the basis of the low accident risk in that type of employment.

\section{The Impact of Legislation on Health and Safety Committees}

Safety representatives were an entirely new concept in British industrial relations when introduced by the 1974 HASAW Act, but as we have seen, voluntary joint health and safety committees have a long history. What, then, was the impact of the legislation on their establishment?

The first evidence on this question came from the Warwick University Industrial Relations Research Unit Survey of 970 establishments. This was conducted between December 1977 and January 1978 and therefore predates the implementation of the SRSC Regulations by almost a year. However, the detail of the impending legislation was already known and thus this survey allows us to consider the impact of the legislation before it was finally implemented. The results revealed that fully 82.1 percent of the 970 establishments surveyed stated that they had a health and safety committee. However, nearly 45 percent of these committees had only been established after the publication of the HASAW Bill 1974. The detailed results for individual industries are set out in Table 3.

The results of this survey confirm the basic conclusions of the 1967 and 1969 Factory Inspectorate surveys, namely that plants in high accident risk industries were more likely to voluntarily establish health and safety committees. Thus shipbuilding and metal manufacture top our list of voluntarily established committees, while the low risk industry groups, leather and clothing and footwear come out bottom of our league table. Even under the shadow of the legislation, as column 3 shows, it is these same low risk industries which still do not all have committees.

Similar results were found in the 1979 Health and Safety Executive Survey which took place exactly one year after the implementation of the Regulations. They found the size 
Table 3 Joint health and safety committees by industry (percent)

\begin{tabular}{|c|c|c|c|c|}
\hline Industry & $\begin{array}{l}\text { Voluntarily } \\
\text { established } \\
\text { (1) }\end{array}$ & $\begin{array}{c}\text { Committees } \\
\text { established } \\
\text { since publication } \\
\text { of the } 1974 \text { Bill } \\
\text { (2) }\end{array}$ & $\begin{array}{l}\text { No. } \\
\text { committees } \\
(3)\end{array}$ & $\begin{array}{c}\text { Total } \\
\text { establishments } \\
\text { (4) }\end{array}$ \\
\hline Food, drink and tobacco & 40.0 & 43.6 & 15.5 & 110 \\
\hline Coal and petroleum & 40.0 & 60.0 & - & 5 \\
\hline Chemicals & 50.7 & 37.7 & 11.6 & 69 \\
\hline Metal manufacture & 59.2 & 27.6 & 10.5 & 76 \\
\hline Mechanical engineering & 45.8 & 34.4 & 18.8 & 96 \\
\hline Instrument engineering & 52.9 & 29.4 & 17.7 & 17 \\
\hline Electrical engineering & 38.5 & 43.8 & 14.6 & 96 \\
\hline Shipbuilding & 81.8 & - & 18.2 & 11 \\
\hline Vehicles & 53.7 & 32.8 & 13.4 & 67 \\
\hline \multicolumn{5}{|l|}{$\begin{array}{l}\text { Metal goods not elsewhere } \\
\text { specified }\end{array}$} \\
\hline $\begin{array}{l}\text { specined } \\
\text { Textiles }\end{array}$ & $\begin{array}{l}39.0 \\
53.0\end{array}$ & $\begin{array}{l}42.1 \\
28.8\end{array}$ & $\begin{array}{l}19.0 \\
18.2\end{array}$ & $\begin{array}{l}95 \\
66\end{array}$ \\
\hline Leather, leather goods and fur & 18.2 & 54.6 & 27.3 & 11 \\
\hline Clothing and footwear & 17.9 & 47.8 & 32.8 & 67 \\
\hline Bricks, pottery, glass, cement & 44.0 & 44.0 & 12.0 & 25 \\
\hline Timber, furniture & 40.6 & 28.1 & 31.3 & 32 \\
\hline Paper, printing and publishing & 47.1 & 29.9 & 23.0 & 87 \\
\hline Other manufacturing & 47.5 & 32.5 & 17.5 & 40 \\
\hline Total & 44.4 & 36.7 & 17.9 & 970 \\
\hline
\end{tabular}

variable to be important in that the majority of all workplaces surveyed in the 251-500 employee range, and larger, had a safety committee before the regulations took effect. Table 4 shows the industry breakdown of safety committees in those workplaces where the survey had found safety representatives. Again the tendency is for workplaces in industry orders with a high accident risk to be more likely to have safety committees than those in the less risky industries. It is also clear that in the manufacturing industry sector these same industries are the ones most likely to have established safety committees as a result of the Regulations. Thus half the committees in clothing and footwear and 40 percent in electrical engineering were established after the Regulations. The impact of the Regulations in public sector industries is even more marked. Well over half of the committees in gas, electricity and water, public administration and defence, and professional and scientific services were established as a result of the Regulations.

Another possible outcome of the impact of legislation is that existing (voluntarily established) committee arrangements can be significantly altered. In the case of health and safety committees this could include the inclusion of trade union safety representatives instead of, or as well as, employee representatives, more regular meetings, changes in size, or changes in the level of management involvement. The Health and Safety Executive survey shows that an average of 20 percent of health and safety committees had been altered as a result of the Regulations. Again there was a degree of inter industry variation in this as is detailed in column 3 of Table 4.

The Health and Safety Executive survey also revealed variations in provision related to size of establishment. In every size range, the majority of workplaces with safety representatives also had safety committees. This was more so in the larger workplaces, but also surprisingly in the very smallest. There was also a marked tendency for larger (i.e. over 501 employees) workplaces to have more than one safety committee, more often as not in a tiered structure. However, it is important to note that there is an inverse relationship between size of establishment and the existence of a safety committee as a result of the Regulations. Thus fully 60 percent of establishments with less than 10 employees with 
safety committees established them after 1978 , compared to only 16 percent of those establishments with over 1,000 employees. The opposite relationship holds for committees altered as a result of the Regulations. This was more likely to have happened in larger establishments where from our earlier evidence it is more likely that committees existed to be altered.

Table $4 \quad$ Safety committees in workplaces with safety representatives classified by industry

\begin{tabular}{|c|c|c|c|}
\hline SIC order & $\begin{array}{l}\text { Percentage of } \\
\text { workplaces (a) } \\
\text { which had a } \\
\text { afety committee(s) } \\
\text { (1) }\end{array}$ & $\begin{array}{l}\text { Percentage of } \\
\text { workplaces (a) with a } \\
\text { safety committee(s) } \\
\text { where the committee } \\
\text { resulted from the } \\
\text { regulations } \\
\text { (2) }\end{array}$ & $\begin{array}{l}\text { Percentage of } \\
\text { workplaces (a) with a } \\
\text { safety committee(s) } \\
\text { where the committee } \\
\text { was altered as result } \\
\text { of the } \\
\text { regulations } \\
\text { (3) }\end{array}$ \\
\hline Coal and petroleum products & $100(\mathrm{~b})$ & 22 & 11 \\
\hline Shipbuilding & $100(\mathrm{c})$ & 17 & 33 \\
\hline Instrument engineering & $100(d)$ & 0 & 50 \\
\hline Gas, electricity and water & 97 & 54 & 9 \\
\hline Chemicals and allied industries & 97 & 13 & 38 \\
\hline Mines and quarries & 96 & 51 & 12 \\
\hline Distributive trades & 95 & 35 & 30 \\
\hline Vehicles & 95 & 29 & 17 \\
\hline Food, drink and tobacco & 94 & 29 & 29 \\
\hline Transport and communication & 94 & 33 & 6 \\
\hline Other manufacturing industries & 94 & 30 & 24 \\
\hline Bricks, pottery, glass, cement & 92 & 30 & 26 \\
\hline Metal manufacture & 90 & 19 & 23 \\
\hline Textiles & 90 & 18 & 21 \\
\hline Metal goods nes & 88 & 39 & 19 \\
\hline Electrical engineering & 86 & 40 & 23 \\
\hline Mechanical engineering & 82 & 32 & 18 \\
\hline Miscellaneous services & 77 & 48 & 23 \\
\hline Paper, printing and publishing & 75 & 29 & 27 \\
\hline Clothing and footwear & 71 & 50 & 20 \\
\hline Agriculture, forestry and fishing & 70 (e) & 70 & 30 \\
\hline Construction & 69 & 59 & 14 \\
\hline Timber and furniture & 65 & 53 & 27 \\
\hline Public administration and defence & 64 & 56 & 24 \\
\hline $\begin{array}{l}\text { Professional and scientific } \\
\text { services }\end{array}$ & 48 & 58 & 24 \\
\hline Overall & 81 & 39 & 20 \\
\hline
\end{tabular}

Notes:

(a) Workplaces where safety representatives had been appointed.

(b) A small sample of six establishments.

(c) A small sample of two establishments.

(d) A small sample of ten establishments.

(e) A small sample of nine establishments.

These then were the basic findings of the two large scale surveys carried out in Britain after the passing of the Health and Safety at Work Act which studied the impact of that legislation. There were clearly considerable inter-industry variations in this impact. We have suggested some of the possible reasons for this: accident risk, plant size, union density, public and private sector. It is to a further analysis of the impact of these and other explanatory variables that we now turn, hopefully to suggest a model to study the impact of industrial relations legislation that will be of use not only in Britain but also in other systems. 


\section{Modelling Variations in the Impact of Industrial Relations Law ${ }^{1}$}

As we saw in previous sections it is relatively easy to come up with a number of ad hoc factors that appear to be related to variation in the response to industrial relations legislation. In this regard one frequently finds the suggestion that large sized plants will be among the leading responders to legislation, although the exact reason for this size influence is rarely spelled out in any detail. Moreover, it is not always clear whether it is the influence of size per se, or rather the fact that size is positively and significantly correlated with a number of other, potential influences, such as the extent of workforce unionisation. For example, the Department of Employment commissioned study of management responses to the industrial relations legislation of the seventies, which we referred to earlier, did little more than consider in a very ad hoc way the influence of plant size and the extent of union organisation in accounting for variation in the impact of the legislation at the establishment level. In this section we attempt to (i) organise (under appropriate sub-headings) and (ii) extend the range of potentially relevant influences beyond that normally put forward in such studies. Accordingly, with a view to trying to provide a more systematic and comprehensive framework of explanation we put forward a model which consists of the following three sub-sectors of variables: (i) variation in the incidence and extent of concern over the problem involved (in this particular case, health and safety matters); (ii) variation in the extent of union power; and (iii) variation in the personnel orientation of management. The potential value of this model was tested by trying to account for inter-industry variation in the extent to which the safety representative regulations had been invoked in their first year of operation i.e. our dependent variable was column 4 of Table 2.

Under the first sub-heading we seek to account for variation in the extent of concern over health and safety matters. In this regard the first variable that we employed was the industry accident rate which we saw as an important source of concern with health and safety matters. The industry accident rate is important not only in its own right, but also because of its positive and significant correlation with other objective characteristics and behavioural manifestations of a poor quality working environment. In addition to the accident rate variable, we sought a variable that would constitute an institutional manifestation of the extent of concern with health and safety matters. The variable utilised for this purpose was the extent of the voluntary establishment of joint health and safety committees. These joint health and safety committees, which were established prior to the passage of the Health and Safety at Work Act 1974, are viewed as adaptive structures which represent an institutional response to a perceived problem of workplace health and safety.

The simple existence of a problem of workplace health and safety will not necessarily guarantee a relatively rapid introduction of the safety representative regulations. The fact of the matter is that there are numerous detailed issues and potential problems that have to be resolved in the course of union-management discussions and negotiations before these regulations are likely to come into operation. The perspective adopted here is that unionmanagement agreement over such matters is likely to be substantially facilitated (i.e. such negotiations are likely to be significantly shortened), with the result that the regulations had been invoked during the period of time under examination in the presence of various sources and manifestations of union power.

The resolution of partially conflicting union-management interests through the exercise of structurally based sources of power is central to the industrial relations paradigm, although the task of devising a fully comprehensive set of empirical proxies for the concept of union power is admittedly a far from straightforward one. The most widely used

1 This section summarises results presented, and tested, in Beaumont (1981). 
individual organisational proxy for union power has undoubtedly been the extent of workforce organisation. This particular variable is held to measure the potential elasticity of substitution between organised and unorganised labour. Accordingly, we used collective agreement coverage as a measure of the extent of workforce organisation, hypothesizing that, the higher collective agreement coverage for male manual workers, the more likely that the safety representative regulations would have been invoked in their first year of operation.

Under this union power sub-vector we also need to consider the specific development of shopfloor organisation for collective bargaining purposes. The potential importance of this consideration follows from the general argument that the shopfloor has enjoyed substantial power gains in relation to both management and the official union structure in the relatively full employment environment of the post-war years. In a series of case studies one could seek to measure, or proxy, the extent of development of shopfloor organisation for collective bargaining purposes by reference to variables such as average shop steward constituency size, the extent of development of hierarchy within this body (e.g. appointment of senior shop stewards) the regularity of steward meetings, etc. However, as these particular variables are rarely available on a systematic industry by industry basis we had to utilise the nature of bargaining structure as a proxy for the extent of development of shopfloor organisation for collective bargaining purposes. The basic contention here was that the greater the extent of single employer bargaining (conducted at the plant and to a lesser extent the company level), as opposed to multi-employer, industry level bargaining, the greater was the extent and nature of union development and power at the shopfloor. And hence the more likely it was that the safety representative regulations would have been invoked during this period of time.

If one moves away from essentially organisational measures or proxies of union power to take a more behavioural orientated perspective then the particular proxy that has traditionally been utilised for this purpose is the incidence or frequency of strikes. However, this particular variable has a number of potential limitations as a proxy for union power. In this regard one could, for example, argue that it may be the threat of a strike, rather than the actual carrying out of this threat, that is the really important dimension of union power. If this is in fact the case then it is arguable that the unions in a really powerful bargaining position rarely have to go on strike; the simple threat to do so is sufficient to achieve their negotiating aims. A second possible limitation of strike frequency as a proxy for union power is that it does not take account of the fact that union power can be exerted or manifested through other means than strikes, such as go-slows, work to rules, overtime bans, etc. Despite these $a$ priori reservations we followed traditional practice and entered strike frequency as a behavioural proxy for union power, predicting a positive sign on the variable. However, we did broaden the notion of the strike as a major instrument of union power by entering as a variable the working days lost dimension of strike activity.

The implicit assumption underlying the sub-vector of union power variables outlined above is that the extent of management opposition to the relatively rapid introduction of the safety representative regulations was essentially a constant actross establishments and industries. In practice, however, it was almost certainly the case that not all managements were equally opposed to the introduction of these regulations, a fact that has obvious implications for the speed with which union-management agreement over their details was reached. Accordingly, the basic argument underlying the third and final sub-vector of variables outlined here is that those managements that accord personnel matters a relatively high priority in their decision making calculus will have been relatively disposed towards the introduction of the safety representative regulations. 
Under this third and final sub-vector we, firstly, entered establishment size as a variable. The use of the size variable as a proxy for the personnel orientation of management follows from the results of a number of studies which have indicated that larger plants devote proportionately more resources to their personnel management function than their smaller sized counterparts, possibly because of the alleged non-pecuniary disadvantages of employment in the more structured, regimented environment of larger plants. As a second potential source of influence we need to take account of the traditional organisational development and change literature which has so strongly stressed the importance of the senior management role in the successful initiation of a change effort. In keeping with our general line of argument concerning the importance of the extent of the personnel orientation of management in this process we hypothesized that where there was a person with a specialist responsibility for industrial relations and personnel matters present on the board or most senior level of decision making within the organisation then there was a significant likelihood of the safety representative regulations having been invoked during the period of time under scrutiny. The basic argument here is that where the personnel management function has attained such relatively high status within the management decision making hierarchy this has the effect of making the individual establishment's management especially conscious of, and responsive to, the provisions of industrial relations legislation.

Finally, we entered a public sector dummy variable, hypothesizing that there was a significantly greater likelihood of the regulations having been invoked in industries predominantly or solely in the public sector. This expectation follows from the Government's acceptance of an obligation to act as a 'good employer' of labour in the public sector. This good employer obligation has frequently placed the public sector to the forefront of the process of introducing new institutional arrangements and structures in the industrial relations field in Britain. Accordingly, we hypothesized that this good employer influence in the public sector would have been at work in encouraging a relatively rapid introduction of the safety representative regulations.

The correlation and regression results obtained indicated that the safety representative regulations were most likely to have been invoked in their first year of operation in industries characterised by high accident rates, high collective agreement coverage, single employer bargaining, large sized establishments, establishments where there was a member of senior management specifically responsible for industrial relations and personnel matters and industries in the public sector. The strength of these preliminary results were such as to encourage us in the belief that the basic model outlined here could be usefully developed and refined to consider the impact of legislation in other subject areas both in Britain and elsewhere. Certainly the basic framework of analysis, and individual hypotheses generated, would seem a substantial advance over previous, ad hoc discussions of the factors likely to influence individual firm response to industrial relations legislation.

\section{Conclusions}

The aims and content of this paper may be summarised relatively briefly. The paper took as its starting point one of the major changes in the British system of industrial relations from the 1970s, namely the substantially increased legal regulation of the system. One of the basic reasons for this change was identified by examining the failure of the attempt to bring about the satisfactory development of joint health and safety committees on a voluntary basis. This failure led directly to the passage of enabling legislation in 1974 . The substantial impact of this legislation was then documented and we concluded by presenting a framework of analysis that seemed to have considerable potential for explaining variation among firms in the response to such industrial relations legislation. 


\section{References}

Beaumont, P.B. (1981) Explaining variation in the enterprise response to industrial relations legislation : the case of the safety representative regulations Personnel review $10(2): 11-15$

Daniel, W.W., E. Stilgoe (1978) The impact of employment protection laws London, PSI.

Kahn-Freund, O. (1969) Industrial relations and the law - retrospect and prospect British journal of industrial relations 7 (3) : 301-316.

Lewis, R. (1976) The historical development of labour law British journal of industrial relations 14 (1) : 1-17.

Phelps Brown, E.H. (1954) The growth of British industrial relations London, Macmillan. Rees, R., N. Robinson (1979) Jobs and the law Management today January : 29-32.

Williams, J. (1960) Accidents and ill-health at work London, Staple Press.

\section{WE FOUND IT IN OUR FILES}

... the Minister of Labour (the Hon. T.P. Shand) . . . said . . . when he addressed the Canterbury-Westland division of the National Party ...

"The day we reach the stage that the Government lays down all the conditions of employment and wages to be paid for labour, it will have stepped over the boundary into the sort of Government that ends up in dictatorship."

Christ church Star 29 May 1963 